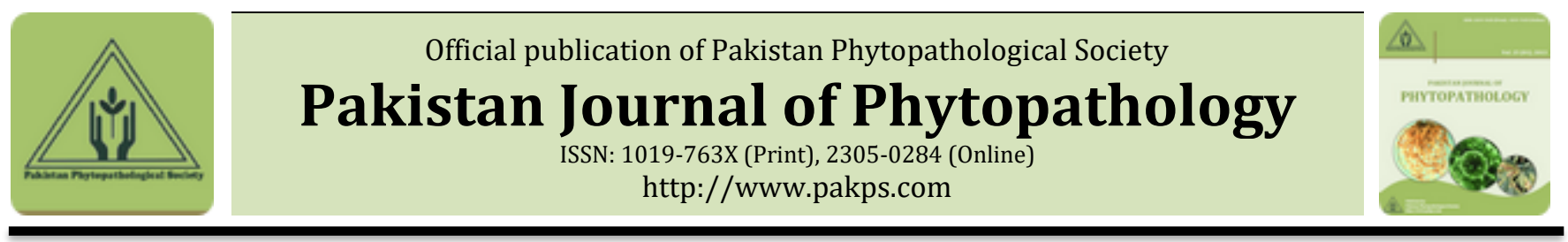

\title{
BIOLOGICAL CONTROL OF PLANT PATHOGENS BY USING ANTAGONISTIC BACTERIA: A REVIEW
}

\author{
aHajra Azeem, aAmjad Ali*, bMuhammad A. Zeshan, bYasir Iftikhar, cWaqas Ashraf, \\ dMuhammad U. Ghani, bAshara Sajid, eAsima Tariq, aMuhammad Sajid \\ a Department of Plant Pathology, Bahauddin Zakariya University, Multan. Pakistan. \\ ${ }^{b}$ Department of Plant Pathology, College of Agriculture, University of Sargodha, Sargodha. Pakistan. \\ c Department of Plant Pathology, Faculty of Agri. and Environmental Sci., The Islamia University Bahawalpur. Pakistan. \\ ${ }^{d}$ Institute of Soil and Environmental Sciences, University of Agriculture Faisalabad. Pakistan. \\ ${ }^{e}$ Institute of Microbiology, University of Agriculture Faisalabad. Pakistan.
}

\begin{abstract}
A B S T RA C T
The application of synthetic pesticides viz fungicide, bactericide, and nematicide to control the harmful phytopathogens that have a terrible impact on all living environments. Therefore, the developing countries have banned the further application of pesticides and usage of an alternate approach than synthetic pesticides, which have no side effect on plant health, human health, and on the living environment that are more cost-effective and ecofriendly behavior. The term biological control through beneficial microorganisms is an alternative approach to control the phytopathogens, which causes severe loss to important crops worldwide. This review article has focused on the antagonistic behavior of bacteria against fungal plant pathogens, bacteria, and nematodes. The bacterial species, especially Bacillus, Pseudomonas, and Streptomyces applied as antagonists against bundles of phytopathogens by a different mode of action. The antagonistic bacteria produce different antimicrobial compounds to suppress the growth of targeted pathogens. To suppress the growth of pre and post harvested fungal and bacterial pathogens, the biocontrol (BC) bacteria produce siderophore, antibiosis, parasitism, competition for space and nutrients, and biofilm formation. Induction of resistance in host plants also generated by biocontrol bacteria through the production of Indole acetic acid (IAA) and activities of the effector genes in host. The commercial products prepared by using the antagonistic bacteria such as Cryptococcus albidus, Pseudomonas syringae, Bacillus subtilis, Candida oleophila' and Aureobasidium pullulans used to control the different phyto-fungal pathogens. This review article covers the threeparts, in the first part, we discussed the antagonistic potential of bacteria against fungal pathogens, in the second part, we discuss the antagonistic potential of bacteria against bacterial pathogens and third part contain the antagonistic potential of bacteria against plant-parasitic nematodes.
\end{abstract}

Keywords: Biocontrol agent, antagonistic bacteria, bacteria against bacteria, biological control of phytopathogen, biofilm formation, siderophore, antibiosis, commercial product.

\section{INTRODUCTION}

Plants are indeed connected in different ways with assorted microorganisms(Yadav et al., 2017). Among these microorganisms, antagonistic bacteria are one that colonizes the aboveground part, seeds, and roots of plant

\footnotetext{
Submitted: September 09, 2020

Revised: December 07, 2020

Accepted for Publication: December 09, 2020

* Corresponding Author:

Email: kambohsaab135uos@gmail.com

(C) 2017 Pak. J. Phytopathol. All rights reserved.
}

without any damaging to host cell. (Liu et al., 2017). Bacteria testified as endophytes consist of momentous gram-positive along with gram-negative bacteria naturally belongs to three significant genera (Alpha, Beta, and Gamma proteobacteria). Even though findings related to endophytic bacteria have not much dedication, it's the most beneficial trait of microbiological studies. Plant growth was significantly indorsed by the endophytic bacteria, retain the capability of phosphate solubilization as well as distribute the nitrogen to plant. Additionally, phytohormones production is linked with 
plant-growth promoting action and enzymes entangled with growth metabolism (Taghavi et al., 2009). Bacteria as plant pathogens can inhabit and colonize the ecological region of plant and have broadly recognized mechanisms regarding biocontrol activity like competition on an ecological region for space, assembly of general inhibitory chemicals, and systemic resistance brought against pathogens in the host plant (Zhuang et al., 2007). The process of ecosystem restoration in a real manner helped the plant in growth with the comfort of plant and bacteria interaction. Bacterial endophytic species can survive on different host plant species.

In the past few decades, chemical fungicides have had a critical role in controlling plant diseases and increasing crop yield. Until now, suppression of soil-borne pathogens mainly relied on chemical pesticides. However, recently, scientists have reported that longterm use of chemical agents can cause adverse effects, including environmental contamination, resistant-plant pathogen outbreak, progressively higher production costs owing to the over-expenditure on these chemicals, and even toxicity in humans. Fortunately, biological control, using antagonistic bacteria as biocontrol agents (BCAs) that interfere with plant pathogens, could be an alternative to chemical control measures and could avoid the problems caused by chemical methods for plant protection(Tan et al., 2006). Biological control agents (also called biocontrol agents or BCA) can play an essential role in suppressing root pathogens in soilless systems. Biocontrol agents are those products that control plant pathogens or pests or reduce their amount or their effect by one or more organisms other than a man (i.e., viruses, bacteria, fungi, and insects). Among the action mechanisms proposed is Mycoparasitism, with the concomitant production of enzymes by the microbes that degrade cell walls. Chitinolytic enzymes, together with $ß$-glucanases or cellulases, are the enzymes most frequently considered critical in biocontrol (Wang et al., 2019). These antifungal proteins such as chitinases, glucanases are of great biotechnological interest because of their potential use as food and seed preservative agents and for engineering plants for resistance to phytopathogenic fungi. As antifungal activity is the most common feature for bacterial species, thus antagonistic bacteria are considered as an ideal biological control agents. The bioactive compound produced by bacteria may act as suppressors or/and inhibitors in the development of phytopathogens (Feichtmayer et al., 2017).

Mechanism of action used by antagonistic bacteria against fungal plant pathogens: Bacteria follow a minimum of two methods of antagonism for the hindrance of various microscopic organisms, which have characteristics of controlling various fungal diseases(Safdarpour and Khodakaramian, 2019). Through parasitism and competition method, bacteria species compete with other fungal pathogens. Mostly the biocontrol bacteria are applied against the post harvested fungal pathogen and sometimes applied against the pre-harvested fungal pathogen in field condition. Here are a few examples of bacteria in which bacteria work as a biocontrol against the fungal pathogen both pre and post harvested conditions (Thokchom et al., 2017; Bahadou et al., 2018) (Tab.1). The mechanism followed by bacteria to suppress the fungal pathogens are mentioned below with detail.

Competition for Space and Nutrients: Food and space competition is a crucial antagonistic mechanism utilized by bacteria for managing various phytopathogens(Di Francesco et al., 2016). Bacteria have the ability to colonize on scratched fruit to ingest the food (Carbon source) for their survival, restricting carbohydrate tendency for fungus, decreasing its germination rate, and accordingly reduced invasion capability on a host (Hernandez-Montiel et al., 2018). Distinctive in vitro investigation has revealed that diverse carbon sources, predominately sucrose, glucose, and fructose, were limited to phytopathogenic fungi by various antagonistic bacteria(Adrees et al., 2019). Limitation to phytopathogenic fungi becomes greater when carbon uptake increased by antagonist; hence, it is crucial to implement studies regarding usage of bacterial antagonists to conclude the lowest application criteria needed to limit the fungi on the host(Asari et al., 2016). Pseudomonas putida is one of the bacteria that repressed the spore germination percentage of $P$. digitatum because of nutrient accessibility on the host(Yu and Lee, 2015). Further, other bacteria known to restrict the diverse infectious fungi utilizing carbon sources are Pseudomonas(Thokchom et al., 2017), Bacillus(Chen et al., 2016), and Pantoea species(Kim et al., 2016).

Siderophore production: Microorganism development relies on an essential component that is iron(Terpilowska and Siwicki, 2019), the stable iron 
oxide multiplex forms when $\mathrm{Fe} 2+$ and $\mathrm{Fe} 3+$ oxidize with each other depending on the availability of water and oxygen. These complex molecule secluded with siderophore; bacteria is responsible for its production as they are peptide molecules having lateral chains along with functional groups which deliver high-affinity towards iron ions(Golonka et al., 2019). Siderophore is distributed into four categories: 1) Catolatephenate 2) pyridoxines 3) Carboxylates and 4) hydroxamates(Carroll and Moore, 2018). Bacteria form siderophore, inhibit, and dislocate pathogenic organisms in host plants. Spore germination was limited by siderophore as well as mycelial growth of
fungus(Cordova-Albores et al., 2016). Antagonistic bacteria was recognized and reported that they produce varied forms of siderophores, some are used by diverse microorganisms, although remaining are particular to each species of bacteria. Their production was identified and proved to be beneficial for bacteria as biological control agent (BCA) by rejecting other pathogenic microorganisms on the plant(Drehe et al., 2018; Zeng et al., 2018). As far as competition was concerned to attain iron, greater inhibition of phytopathogen determine by the formation of siderophore with antagonistic bacteria(Andreolli et al., 2019).

Table 1. Antagonistic capability of bacteria against fungal plant pathogens

\begin{tabular}{|c|c|c|c|}
\hline Bacterial spp. & Fungal pathogens & Host/ Crops & References \\
\hline B. velezensis & F. graminearum & Wheat & (Chen et al., 2018) \\
\hline Streptomyces viridodiasticus & $\begin{array}{l}\begin{array}{l}\text { Fusarium oxysporum } \\
\text { Cubense }\end{array} \\
\text { f. }\end{array}$ & Banana & $\begin{array}{l}\text { (Getha and Vikineswary, } \\
\text { 2002) }\end{array}$ \\
\hline S. ambofaciens $\mathrm{S} 2$ & Colletotrichum gloeosporioides & Chilli & (Heng et al., 2015) \\
\hline Bacillus subtilis & Sclerotinia sclerotiorum & Lactuca sativa & (Monteiro et al., 2013) \\
\hline Pseudomonas chlororaphis & Sclerotinia sclerotiorum & Soybean & (Selin et al., 2009) \\
\hline Bacillus amyloliquefaciens & Penicillium expansum & Apple & (Calvo et al., 2017) \\
\hline Bacillus megaterium & Aspergillus flavus & Peanut & $\begin{array}{l}\text { (Carmona-Hernandez } \\
\text { al., 2019) }\end{array}$ \\
\hline
\end{tabular}

\begin{tabular}{|c|c|c|c|}
\hline Streptomyces yanglinensis & Aspergillus flavus & Peanut & (Shakeel et al., 2018) \\
\hline Bacillus megaterium & Aspergillus flavus & Peanut & (Chen et al., 2019) \\
\hline Bacillus pumilus & Phaeomoniella chlamydospora & Grapevine & (Haidar et al., 2016) \\
\hline $\begin{array}{l}\text { Sphingopyxis sp. TBD } \\
\text { Cupriavidus sp. TBD } 162\end{array}$ & Fusarium oxysporum & Tomato & (wara et al., 2016) \\
\hline $\begin{array}{l}\text { Bacillus subtilis } \mathrm{s} \\
\text { B. amyloliquefaciens }\end{array}$ & Macrophomina phaseolina & Bean & (wws et al., 2016) \\
\hline Bacillus spp. & Penicillium purpurogenum & Strawberries & (Alsohiby et al., 2016) \\
\hline Lactobacillus brevis LPBB 03 & Aspergillus westerdijkia & Coffee beans & $\begin{array}{l}\text { (de Melo Pereira et al., } \\
\text { 2016) }\end{array}$ \\
\hline Bacillus subtilis & Lasiodiplodia theobromae & Rubberwood & (Sajitha and Dev, 2016) \\
\hline Pseudomonas brassicacearum & Verticillium dahliae & Potato & (Novinscak et al., 2016) \\
\hline Bacillus subtilis & Botrytis cinerea & Grapes & (Mu et al., 2017) \\
\hline Bacillus amyloliquefaciens & Fusarium graminearum & Wheat and barley & (e et al., 2017) \\
\hline Bacillus pumilus MSUA3 & $\begin{array}{l}\text { Rhizoctonia solani } \\
\text { F. oxysporum }\end{array}$ & $\begin{array}{l}\text { Fagopyrumesculentum } \\
\text { Moench }\end{array}$ & (Agarwal et al., 2017) \\
\hline $\begin{array}{l}\text { B. cereus } \\
\text { B. mojavensis }\end{array}$ & $\begin{array}{l}\text { M. grisea } \\
\text { F. verticillioides } \\
\text { F. proliferum }\end{array}$ & Rice & $\begin{array}{l}\text { (Agarwal et al., 2017; } \\
\text { Etesami and Alikhani, } \\
\text { 2017) }\end{array}$ \\
\hline
\end{tabular}

Parasitism (Lithic Enzyme Production): Bacterial antagonist acquires feed from phytopathogen as parasitism occurs, engendering complete structure lysis. Bacterial antagonist feeds on the fungal cell wall $30 \%$ protein(Spadaro and Droby, 2016). Erect and insoluble chitin designed by $\mathrm{N}$-Acetyl glucosamine (subunits) that interlinked with $\beta-1,4$, besides, provides 
support to the cell wall(Seidl, 2008). $\beta$-1,3-glucan is one of the essential components of the cell wall, in which several other components are covalently associated, providing mechanical stability as well as integrity. In most cases, proteins related to cell wall are glycoproteins as well as oligosaccharides. The protein associated with cell wall has a significant role in their synthesis, molecular absorption as well as contribute to protection. Diverse enzymes are needed to degrade the fungal protecting cell wall, specifically $\beta$-1,3-glucanase, chitinases, as well as proteases(Safdarpour and Khodakaramian, 2019). Bacteria emit one of the vital enzyme 'glucan' that have the ability to hydrolyze the glucans by following these two significant mechanisms: (a) Exo-1,3-glucanase can hydrolyze the concerned glucans by successive integration of glucose particles by the non-reducer residues, and (b) endo-1,3-glucanase stimulate the association with aleatory spots beside polysaccharide chain, although oligosaccharide, as well as glucose, are found in minor quantity(Spadaro and Droby, 2016). Chitinases are generally hydrolyzed by chitin, non-splitting N-Acetyl glucosamine found in 1,4 linkage by following these two mechanisms: (a) NAG residues successively segmented by exo-chitinase; and (b) aleatory sites concerned with polymer chain activated by the endo-chitinase(Stoykov et al., 2015). As the site of action was concerned, proteases were divided into four essential groups: first one 'serine proteinases', second one 'cysteine proteinases,' third one 'aspartic proteinases', and fouth one 'metalloproteinases'(Barrett et al., 2012). According to last year, diverse studies have been accomplished that is concerned with the production of yeast and bacteria from hydrolytic enzymes(Bahadou et al., 2018). The majority of Bacillus, as well as Pseudomonas genera, contain effective antagonists concerned with controlling pathogenic organisms because uninterruptedly affect the chitinase(Yu et al., 2008). (Shivakumar et al., 2014)concluded his work that kinetic studies, purification, and characterization were performed on chitinase enzyme of concerned $B$. subtilis, here the moderately purified enzyme revealed antifungal activity not only for R.solani, but also against Colletotrichum gloeosporioides.

Formation of Biofilm and quorum sensing: As far as successful colonization on fruit surface was concerned, biocontrol through antagonistic properties associated bacteria was effective that have characteristics to assist their adherence, colonization, as well as multiplication. Due to these characteristics, biofilms were formed that contain micro-colonies among hydrated protein medium created by antagonistic bacteria and measured via quorum sensing with concerned regulators: farnesol, phenethyl alcohol, and tyrosol. The micro colonies concerned with the communication corridor not only release diverse chemical signals employing to supervise the associated environment but also fluctuating the genetic expression as well as attaining benefit over their opponents via quorum sensing(Chi et al., 2015).The biofilms associated with biological control proved as a barrier for phytopathogen by standing between lesions tissues of the host. Although, less information is acknowledged regarding mechanism employed in biofilm formation. The chemical signals on the environment released by bacteria are not only concerned with the regulation of morphogenetic alternations, but also they are responsible for bacteria selection as BC(Beauregard et al., 2013; Chen et al., 2013). Bacillus subtilis is one of the bacteria that have not the only function in forming supporting community by utilizing a growing number of the population having isogenic ancestors, but also involved in macromolecule assembly, production as well as biofilm matrix formation(Vlamakis et al., 2008; Ostrowski et al., 2011). As far as the matrix was concerned abouta bacterium that comprises subsequent proteins TasA or TapA(Branda et al., 2001; Romero et al., 2011) as well as produced the polysaccharide having a large and diverse molecular weight(Branda et al., 2001). The biofilm gathering takes place as long as coating protein over there for biofilm known as BsIA, earlier termed as YuaB(Kobayashi and Iwano, 2012; Kaufman et al., 2017). Scientist work revealed that Paenibacillus polymyxa is beneficial bacteria colonize the majority of plant roots resulting in a structure that appears as biofilm, so this bacteria is involved in protecting the phytopathogens infectious diseases on plant roots(Haggag and Timmusk, 2008). Another bacteria, Pseudomonas fluorescens having strain CHAO, presented their capability in protecting plants by colonizing on carrot plant roots(Bianciotto et al., 2001). B. subtilis have the capability to form biofilm style appearance on Arabidopsis plants and thus inhibit the $P$. syringae infection on the same plant(Bais et al., 2004).

Antibiosis with antimicrobial metabolites: Antimicrobial metabolites consist of secondary 
metabolites, amongst heterogeneous groupshaving an organic compound of less molecular weight produced by concerned microorganisms, which proved to be lethal for the survival of other microbes (Thomashow, 2002). Antimicrobial metabolites, associated through broadspectrum action, have been described that biological control takes place by using these genera of bacteria: Pantoea, Agrobacterium, Serratia, Streptomyces, Pseudomonas, Bacillus, Stenotrophomonas, and others. Genera bacillus, mainly found to be associated with lipoproteins that are iturin, surfactin, and fengycin(Ongena and Jacques, 2008),but Pseudomonas, comprises of antibiotic metabolite like DAPG, phenazine and pyrrolnitrin were discussed in studies(Raaijmakers and Mazzola, 2012). Antibiotics have a significant role in protecting the plant from other growing microbes afterward food and space competition, and thus produced by bacteria having low-molecular-weight, recognized as volatile organic compounds (VOCs) through antibiosis. Three main antibiotics are iturin, trichothecene, and pyrrolnitrin have been emitted by bacteria B. subtilis, Myrothecium roridum, and P. cepacia ,respectively, to control fungal diseases(Torres et al., 2014). Antibiotics are proved to be effective in less concentration associated with chemical groups: alcohols, esters, aldehydes, terpenes, ketones, sulfur compounds, and lactones. Due to their volatile-ability in the environment, they can travel unrestricted distance in solid and liquid medium as well as in gas complexes, having a great advantageous effect as BCA.

Attention to these VOCs was less in the past than other associated antagonistic mechanisms. Although, nowadays, researchers pay attention to products related to volatile metabolism (Fialho et al., 2011). Bio fumigation of fruit was possible via microorganisms that can emit VOCs in locked and protected chambers verified as an excellent alternative source to control some phytopathogens(Guevara-Avendaño et al., 2019). Although, proved to be valuable that BCA release VOCs and their fungistatic activity was known, contribute to control the fungal pathogens. Yet, nearly a few phytopathogens able to introduce a wide-ranging VOC. Therefore, this way has to be evaluated in detail in the subsequent investigation studies (Spadaro and Droby, 2016). Scientists point out the genus Bacillus since effective BCA produces some secondary metabolites that have shown to be biologically energetic, determined with a biochemical summary. The two species are suggested as BCA as a result of this research are Brevibacillus brevis emit the fengycin and iturin A,and Bacillus subtilis emits gramicidin S (1-5) metabolites, which can prevent the growth progress of varied phytopathogens(Layton et al., 2011). Scientists also proved that VOCs were produced by the Arthrobacteragilis. This was introduced for hindrance of Botrytis cinerea and Phytophthoracinnamomi, confirmed with gas chromatography and other analysis, in which dimethyl hexadecylamine was identified in the form of a compound, demonstrating the 12 times more hindrance as compared to fungicide (captan)(Velázquez-Becerra et al., 2013).

Induction of resistance in host plant: Stimulation of resistance includes the $\mathrm{BC}$ bacterium capacity of inciting host defensive chemical and biochemical response, comprising the variation in the assembly of tissues and protein formation interlinked to pathogenesis; their expression occurs locally or either systemically (Fu et al., 2010). Bacteria involvement in inducing resistance proved to be effective as BCA in their action and controlling diseases during storage(Jamalizadeh et al., 2011; Hernandez-Montiel et al., 2018). Defense in host activated and specified by releasing several enzymes along with metabolites, particularly (A) proteins interlinked with pathogenicity (PR proteins), comprises peroxidases, glucanases, catalase(provide tissue protection from oxidative injury),chitinases, protein reducers, superoxide dismutase, or lipid-movement proteins; (B) compound complexes associated with significant antimicrobial action, includes phytoalexins; and (C) Callose involvement in papillae formation and presence of lignin affirming strengthening to the cell wall. Some other arrangements are involved in triggering the immunity comprises (A) reactive oxygen species (ROS) production involved in the signaling process and have undeviating antimicrobial result; and (B) Stomata that leaf going toward closing. The majority of plants have an immune response that is facilitated and reliant on phytohormones, jasmonic acid, abscisic acid, salicylic acid, ethylene, and collaboration between them permitting the beginning of plant insusceptible response to protect against the particular pathogen (Hacquard et al., 2017; Guo et al., 2018).Even though induction of safe plant tissue resistance is interrelated with BCA treatment, evidence related to the substantial capacity that is 
brought to prevent plant disease was not recognized (Spadaro and Droby, 2016).

Commercial biocontrol products of bacteria: Biocontrol was relatively new as compared to the usage of pesticides. One of the bacteria, Agrobacterium radiobacter(K 84 strain), registered during 1979 in the United States for management of crown gall diseases. Fourteen bacteria were registered by the US until 2005. Mostly, they are sold for commercial purposes in the required amount (Fravel, 2005). The commercialization of bioproducts was yet in the preliminary phase, but it provides a safe product in the farmer market.

Biocontrol products depend on the multistep procedure for commercialization (Junaid et al., 2013)comprising many activities are:

A) Phytopathogen isolation through the ecosystem

B) In vitro assessment of bio-agent in greenhouse

C) Analysis in the field for checking good isolate

D) Formulation with the help of mass production

E) Delivery and inspection of compatibility

F) Registration and declared the release in the market

Several bacterial antagonists were identified through laboratory experiments, after field analysis used as biofertilizer commercially in the field (Gotor-Vila et al., 2017). Beneficial bacteria were used for significant product development by removing chemical toxins from the food supply (m et al., 2019). The microorganism was isolated from sea, plant, and soil, used as BCA, which is a costly, complex, and cooperative process. In BCAs studies, much research was conducted; even so, commercial use is paradoxical and limited. The reason behind that, field conditions required high marketable consumption for effective control on a commercial basis. The circumstances depend mainly on the environment that is a variable factor and uncontrollable, including temperature, precipitation, humidity and, abiotic features that are overcome by fungicides and form a significant medium to manage fungal pathogens (Nunes, 2012). Additionally, before beginning the product development of BCAs, they should have much knowledge of numerous factors related to the management of fungal diseases, including involved phytopathogen, host kind on which outbreaks, diseases epidemiology, resistance associated with phytopathogen, as well as environmental circumstances need to know for using BCA. However, future problems arise unless successful antagonist selection takes place. For successful releasing of BCA in the market depends upon the production process that has pass-through diverse studies and developed a scale for acquiring enough quantity of BCA for its effective assessment in a packing plant, field and, glasshouse.

In many cases, product displays enough aspects not only related to their production on economic and technical basics but also their registration along with commercialization (Holert et al., 2018). The primary purpose of the investigation associated with BCAs is to improve and make a desirable product used on a commercial basis. Although many efforts are utilized in $\mathrm{BC}$ research, some product was available commercially on the market (Droby et al., 2016).These few products for BC are used to control the phytopathogens, although considered as first-generation BC products that have antagonistic bacteria. Some products include 'Aspire' Candida oleophila(Blachinsky et al., 2007), 'Candifruit' Candida sake (Teixidó et al., 2011), 'Yieldplus' Cryptococcus albidus(Kowalska et al., 2012), and 'BioSave'Pseudomonas syringae(Janisiewicz and Korsten, 2002). They all were commercially available from a few years ago; although products were decreased in the market and suspension need appear. Moreover, biosave use to control diseases was still limited in the market of US (Janisiewicz and Peterson, 2004). 'Avogreen' Bacillus subtilis used against the spot of Cercosporasp in Africa on the fruit avocado, but unfortunately success not last,the reason behind that was the unreliable result (Demoz and Korsten, 2006).Nexy'Candida oleophila' prepared in Belgium and presented during 2005 for approval and received in 2013 by the European Union against phytopathogens of banana fruit (Sebastien and Jijakli, 2014). Bio-Ferm 'Aureobasidium pullulans' must apply to protect the phytopathogen infection on fruits that are kept in storage (Lima et al., 2015). Pantovital 'Pantoeaagglomerans' was formulated against citrus fruit diseases, but their journey toward commercialization doesn't succeed (Usall et al., 2016). Amylo-X 'Bacillus amyloliquefaciens' produced by Biogard, in Italy, used against many diseases of vegetables. Shemer 'Metschnikowiafructicola' formulated in Israel and effective in controlling postharvest diseases on many fruits such as grapes, 
strawberry, citrus and peach. Shemer production was under Bayer Crop Science, and the latter license was also provided to Koppert(Spadaro and Droby, 2016). Serenade 'Bacillus subtilis' presented by Bayer, it was Table 2. List of antibiotics produced by biocontrol bacteria

\begin{tabular}{|c|c|c|c|c|}
\hline Antibiotic & Source & Targeted pathogen & Disease & Reference \\
\hline $\begin{array}{l}\text { Cyclic lipopeptide } \\
\text { antibiotics (CLPs) }\end{array}$ & B. subtilis & P. digitatum & $\begin{array}{l}\text { Decay on citrus } \\
\text { fruit }\end{array}$ & $\begin{array}{l}\text { (Waewthongrak et } \\
\text { al., 2015) }\end{array}$ \\
\hline Fengycin A & $\begin{array}{l}\text { B.atrophaeus } \\
\text { CAB-1 }\end{array}$ & Sphaerotheca fuliginea, B. cinera & $\begin{array}{l}\text { Cucumber } \\
\text { powdery mildew } \\
\text { Tomato grey } \\
\text { mold } \\
\end{array}$ & (Zhang et al., 2013) \\
\hline Bacillomycin D & $\begin{array}{l}\text { B.velezensis HN- } \\
2\end{array}$ & C. gloeosporioides & $\begin{array}{l}\text { Mango } \\
\text { Anthracnose }\end{array}$ & (Jin et al., 2020) \\
\hline $\begin{array}{l}\text { Iturin } \mathrm{D} \text { and } \\
\text { bacillomycin D }\end{array}$ & B. subtilis & $\begin{array}{l}\text { Xanthomonas oryzae pv. Oryzae } \\
\text { Rhizoctonia solani, Fusarium } \\
\text { verticelloides } \\
\text { and Sclerotiumrolfsii. }\end{array}$ & $\begin{array}{l}\text { Bacterial leaf } \\
\text { blightof rice }\end{array}$ & $\begin{array}{l}\text { (Kumar et al., } \\
\text { 2020) }\end{array}$ \\
\hline Mycostubilin & Bacillus BBG100 & $\begin{array}{l}\text { Pythium } \\
\text { aphanidermatum }\end{array}$ & Damping off & (Junaid et al., 2013) \\
\hline Bacillomycin D & B. subtilis & Rhizopus stolonifera & $\begin{array}{l}\text { Soft rot of } \\
\text { tomato }\end{array}$ & (Lin et al., 2019) \\
\hline Zwitermycin A & B. cereus & Pythium aphanidermatum & Damping off & $\begin{array}{l}\text { (Sarangi et al., } \\
\text { 2017) }\end{array}$ \\
\hline Herbicolin & $\begin{array}{l}\text { Pantoea } \\
\text { agglomerans } \\
\text { E325 }\end{array}$ & E.amylovora & $\begin{array}{l}\text { Apple's } \\
\text { blight }\end{array}$ & (Pusey et al., 2011) \\
\hline Iturin A & $\begin{array}{l}\text { B.subtillus } \\
\text { QST713 }\end{array}$ & Candida Albicans & $\begin{array}{l}\text { Gray and green } \\
\text { mold }\end{array}$ & $\begin{array}{ll}\text { (Ambrico } & \text { and } \\
\text { Trupo, 2017) } & \\
\end{array}$ \\
\hline
\end{tabular}

The antagonistic ability of bacteria against other plants pathogenic bacterial species: Phytopathogen has a damaging effect on the yield of agricultural produce due to the cuts and wounds produced through the harvesting. Bacteria, including Ralstonia, Xanthomonas, Erwinia, and Pseudomonas responsible for softening along with rotting of vegetables and fruits. Bactericide is a chemical, valid for the decay caused by bacteria on the fruits(Di Francesco et al., 2016). Some of these chemical products are not approved and not available in the market because of their toxicological hazards. Furthermore, public fear related to pesticide usage was due to bactericide resistance in bacterial phytopathogen, and a greater cost was needed for new chemical development, so stimulate the search of alternative new approaches(Sharma et al., 2009). Bacterial genera, including Bacillus, Pseudomonas, and Pantoea was valid BCAs, to manage the bacterial phytopathogens. Plant choose most of the bacteria, which are fitness for producing organic compounds by using exudates, generating the environment that has less diversity. In rhizosphere bacteria found abundantly and at greater rate affects the physiology of the plant, verified to be operative in the management of diseases in strawberry, tomato, and peach (Usall et al., 2016). Though, these products are not alternatively effective as compared to synthetic products (Maida et al., 2016). particularly effectiveness to colonize the root was considered. Although bacteria improve the growth of plants by improving limiting conditions and indirectly provide support to growth through secretion of antagonistic substances against phytopathogen and persuading the host resistance(Köhl et al., 2019). Microorganism lives in soil colonize in the rhizosphere is an initial step in pathogenesis. Microbial inoculants are fundamentals utilized in the form of biofertilizers, phytostimulators, bioremediation, and biocontrol agents. For example, Pseudomonas spp is significant bacteria and utilized as a root colonizing model (Lugtenberg and Kamilova, 2009).

In the previous twenty years, the studies conducted related to it cleared that enzymes, volatiles, and antibiotics are some metabolites secreted by bacteria involved in managing various phytopathogens. In many studies, several antibiotics are proved to be broadspectrum secreted by antagonistic bacteria. Their example includes pyrrolnitrin that have broad-spectrum action, Burkholderia and Pseudomonas are responsible for their production, observed previously by the scientist 
in 1960s (Nishida et al., 1965), and this beneficial antibiotic was developed to control bacterial disease. Bacillus amyloliquefaciens are involved in suppressing the damaging phytopathogen by the action of competition, antibiosis, and stimulation of systemic resistance (Diallo Table 3. Examples of biocontrol bacteria against other bacteria

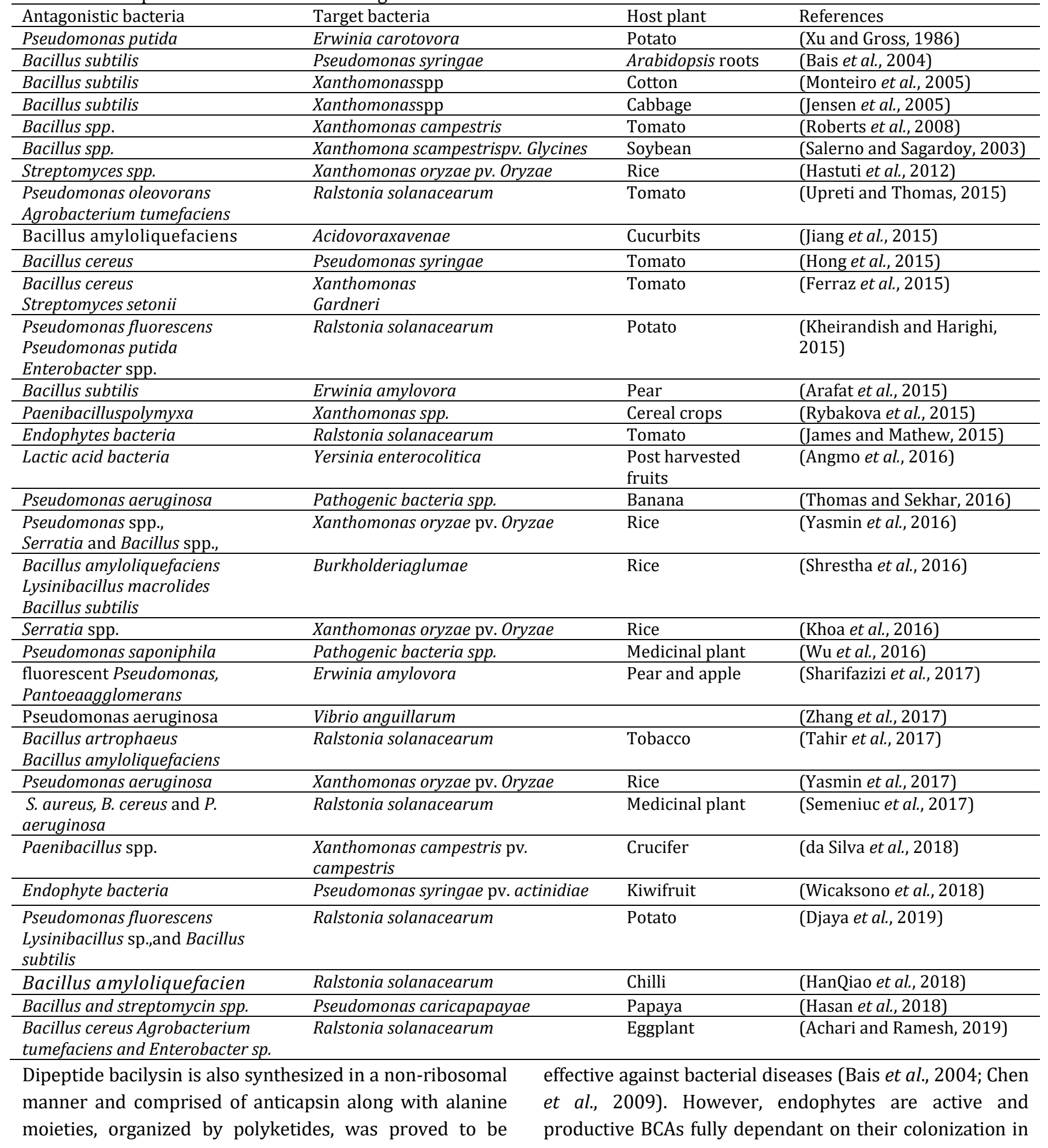

et al., 2011). B. amyloliquefaciens and B. subtilis are responsible for the synthesis of polyketides (bacillaene, macrolactin, and difficidin) in a non-ribosomal manner that is significant and operational antibacterial complex (Chen et al., 2009). 
the surrounding of a plant. Colonization range in the rhizosphere by the endophytes depicts the bacterial pathogen contribution that acclimatizes to live selectively in particular ecological niches (Des Essarts et al., 2016).

The antagonistic ability of bacteria against plant parasitic nematodes: Nematode in the form of plantparasitic entity is amongst the destructive pest of different crops as responsible for the heavy crop losses and cause more harm as compared to insect pests each year (Koenning et al., 1999). Their management seems to be more challenging as compared to other pests because they increase their population in soil and frequently affect the underground portion of the crop (Stirling, 1991). However, chemicals to control nematode as nematicides are easily accomplished in the field and provide simultaneous results. Still, due to its hazardous effects on the environment and health, it is prohibited in many countries for resolving safety issues (Schneider et al., 2003). The need for immediate consideration towards alternatives and innovative products that are environmentally friendly in order to inhibit the nematode population that is gradually becoming significant. Table 4. Examples of biocontrol bacteria against plant-parasitic nematode.

\begin{tabular}{|c|c|c|c|}
\hline Bacteria & Nematode & Host & References \\
\hline $\begin{array}{l}\text { Bacillus subtilis isolates } \mathrm{Sb} 4- \\
23 \\
\text { Bacillus methylotrophicus }\end{array}$ & $\begin{array}{l}\text { Meloidogyne incognita } \\
\text { Meloidogyne incognita }\end{array}$ & $\begin{array}{l}\text { Tomato seed } \\
\text { Tomato }\end{array}$ & $\begin{array}{l}\text { (Adam et al., } \\
\text { 2014) } \\
\text { (Zhou et al., } \\
\text { 2016) }\end{array}$ \\
\hline B. subtilis & Meloidogyne incognita & Tomato & $\begin{array}{l}\text { (Subhalaxmi } \\
\text { et al., 2017) }\end{array}$ \\
\hline Pseudomonas Oryzihabitans & Meloidogyne spp. & Tomato & $\begin{array}{l}\text { (Vagelas and } \\
\text { Gowen, 2012) }\end{array}$ \\
\hline Bacillus firmus & $\begin{array}{l}\text { Caenorhabditis elegans and } \\
\text { M. incognita }\end{array}$ & Different crops & $\begin{array}{l}\text { (Geng et al., } \\
\text { 2016) }\end{array}$ \\
\hline $\begin{array}{l}\text { B. subtilis } \\
\text { B. laterosporus } \\
\text { Bacillus spp } \\
\text { Arthrobacterspp } \\
\text { Lysobacterspp }\end{array}$ & $\begin{array}{l}\text { Meloidogyne javenica } \\
\text { Heteroderaglycines } \\
\text { Panagrellusredivius } \\
\text { Meloidogyne chitwoodi } \\
\text { Pratylenchusneglectus }\end{array}$ & $\begin{array}{l}\text { Different crops } \\
\text { Different crops } \\
\text { Potato }\end{array}$ & $\begin{array}{l}\text { Xia et al., } \\
\text { 2011) } \\
\text { (Tian et al., } \\
\text { 2007) } \\
\text { (Castillo et al., } \\
\text { 2017) }\end{array}$ \\
\hline $\begin{array}{l}\text { Pseudomonas aeruginosa } \\
\text { Paenibacilluspolymyxa } \\
\text { B. subtilis } \\
\text { Pratylenchus penetrans }\end{array}$ & $\begin{array}{l}\text { Meloidogyne incognita } \\
\text { Meloidogyne hapla }\end{array}$ & $\begin{array}{l}\text { Different crops } \\
\text { Tomato }\end{array}$ & $\begin{array}{l}\text { (Soliman et al., } \\
\text { 2019) } \\
\text { (Topalović et } \\
\text { al., 2019) }\end{array}$ \\
\hline $\begin{array}{l}\text { Bacillus, Serratia, } \\
\text { Paenibacillus, Enterobacter } \\
\text { and Streptomyces spp. }\end{array}$ & $\begin{array}{l}\text { Meloidogyne, Pratylenchus, } \\
\text { Apratylenchus, Criconemella } \\
\text { and Xiphinema spp. }\end{array}$ & Coffee & $\begin{array}{l}\text { (Hoang et al., } \\
2020 \text { ) }\end{array}$ \\
\hline $\begin{array}{l}\text { Bacillus, Corynebacterium, } \\
\text { Streptococcus, and } \\
\text { Staphylococcus spp. }\end{array}$ & Meloidogyne incognita & Tomato & $\begin{array}{l}\text { (Colagiero et } \\
\text { al., 2020) }\end{array}$ \\
\hline Pasteuria spp. & $\begin{array}{l}\text { Helicotylenchusdigonicus, } \\
\text { Pratylenchusthornei, P. neglectus, } \\
\text { Geocenamusbrevidens, } \\
\text { Tylenchhorhynchuscylindricus, } \\
\text { Rotylenchuscypriensis, } \\
\text { Meloidogyne javanica, and } \\
\text { M.incognita }\end{array}$ & $\begin{array}{l}\text { Olive, peach, cherry, } \\
\text { walnut, pear, vineyards, } \\
\text { almond, sunflower, } \\
\text { apple orchards and } \\
\text { vegetable crop }\end{array}$ & $\begin{array}{l}\text { (Öztürk et al., } \\
\text { 2020) }\end{array}$ \\
\hline
\end{tabular}

As we knew, the nematode population generally survives in the soil and is available to pathogenic bacteria and fungi to manage the nematode (Mankau, 1980; Jatala, 1986). Bacterial genera that are subjected to biological control include Pseudomonas,Bacillus, and Pasteuria that are found abundantly in the soil and have pronounced potential to control the nematode population. The modes utilized by the bacteria are numerous to eradicate the nematode: such as the ability to parasitize, production of antibiotics, toxins and enzymes that are 
intrusive in recognition of nematode by the host, competing and opposing for the accessible nutrients as well as persuading the host resistance, and encouraging proper plant development. Exploitive activities of bacteria luinematode population, such as predacious or free-living nematodes and parasitic nematodes(Mankau, 1980; Stirling, 1991; Siddiqui and Mahmood, 1999). The formation of complex linkage between bacteria and the nematodes, host, and condition of the environment to manage the nematode population in ordinary circumstances. Bacteria also have the capacity to mobilize and activates the fungi to kill the pathogenic nematodes that are problematic in agriculture (Wang et al., 2010).Pasteuria penetransareparasitic bacteria and destroy the Meloidogyne spp. that are responsible for the formation of root-knots in their host plant. Pasteuria forms spores that adhere to the cuticle of particularly second-phase juvenile, although their germinate begun as they arrived in host root and start nourishing. The capacity of cuticle penetration is through germ tubes result in the formation of vegetative microcolonies and proliferate on the body of an emergent female of a nematode. Although female nematode's reproductive system typically degenerate and responsible for the release of endospores in the soil (Mankau et al., 1976; Sayre and Wergin, 1977). Spore adherence toa nematode cuticle is the initial phase of infection development (Davies et al., 2001). Conversely, the reproductive structure of Pasturia doesn't recognize every nematode species because they have a limited host series such as Pas. penetrans inhibit the Meloidogyne spp., Pas. nishizawae inhibit the nematode of genera Heterodera and Globoderaand Pas. thornei liable to inhibit the Pratylenchusspp(Mendoza de Gives et al., 1999; Atibalentja et al., 2000).

\section{REFERENCES}

Achari, G. A. and R. Ramesh. 2019. Colonization of Eggplant by Endophytic Bacteria Antagonistic to Ralstonia solanacearum, the Bacterial Wilt Pathogen. Proceedings of the National Academy of Sciences, India Section B: Biological Sciences, 89: 585-593.

Adam, M., H. Heuer and J. Hallmann. 2014. Bacterial antagonists of fungal pathogens also control rootknot nematodes by induced systemic resistance of tomato plants. PloS one, 9: e90402.

Adrees, H., M. S. Haider, T. Anjum and W. Akram. 2019. Inducing systemic resistance in cotton plants against charcoal root rot pathogen using indigenous rhizospheric bacterial strains and chemical elicitors. Crop protection, 115: 75-83.

Agarwal, M., S. Dheeman, R. C. Dubey, P. Kumar, D. K. Maheshwari and V. K. Bajpai. 2017. Differential antagonistic responses of Bacillus pumilus MSUA3 against Rhizoctonia solani and Fusarium oxysporum causing fungal diseases in Fagopyrum esculentum Moench. Microbiological research, 205: 40-47.

Alsohiby, F. A. A., S. Yahya and A. A. Humaid. 2016. Screening of soil isolates of bacteria for antagonistic activity against plant pathogenic fungi. PSM Microbiology, 1: 5-9.

Ambrico, A. and M. Trupo. 2017. Efficacy of cell free supernatant from Bacillus subtilis ET-1, an Iturin A producer strain, on biocontrol of green and gray mold. Postharvest Biology and Technology, 134: 5-10.

Andreolli, M., G. Zapparoli, E. Angelini, G. Lucchetta, S. Lampis and G. Vallini. 2019. Pseudomonas protegens MP12: A plant growth-promoting endophytic bacterium with broad-spectrum antifungal activity against grapevine phytopathogens. Microbiological research, 219: 123-131.

Angmo, K., A. Kumari and T. C. Bhalla. 2016. Antagonistic activities of lactic acid bacteria from fermented foods and beverage of Ladakh against Yersinia enterocolitica in refrigerated meat. Food bioscience, 13: 26-31.

Arafat, K. H., S. A. Hanan and M. R. Abd-El-Aziz. 2015. Antibacterial activity of antagonistic bacteria and plant extract on Erwinia amylovora the pathogen of fire blight disease in Egypt. International Journal of Phytopathology, 4: 73-79.

Asari, S., S. Matzén, M. A. Petersen, S. Bejai and J. Meijer. 2016. Multiple effects of Bacillus amyloliquefaciens volatile compounds: plant growth promotion and growth inhibition of phytopathogens. FEMS Microbiology Ecology, 92: fiw070.

Atibalentja, N., G. Noel and L. Domier. 2000. Phylogenetic position of the North American isolate of Pasteuria that parasitizes the soybean cyst nematode, Heterodera glycines, as inferred from 16S rDNA sequence analysis. International Journal of Systematic and Evolutionary Microbiology, 50: 605-613. 
Bahadou, S. A., A. Ouijja, A. Karfach, A. Tahiri and R. Lahlali. 2018. New potential bacterial antagonists for the biocontrol of fire blight disease (Erwinia amylovora) in Morocco. Microbial pathogenesis, 117: 7-15.

Bais, H. P., R. Fall and J. M. Vivanco. 2004. Biocontrol of Bacillus subtilis against infection of Arabidopsis roots by Pseudomonas syringae is facilitated by biofilm formation and surfactin production. Plant physiology, 134: 307-319.

Barrett, A. J., J. F. Woessner and N. D. Rawlings. 2012. Handbook of Proteolytic Enzymes, Volume 1. Elsevier.

Beauregard, P. B., Y. Chai, H. Vlamakis, R. Losick and R. Kolter. 2013. Bacillus subtilis biofilm induction by plant polysaccharides. Proceedings of the National Academy of Sciences, 110: 1621-1630.

Bianciotto, V., S. Andreotti, R. Balestrini, P. Bonfante and S. Perotto. 2001. Mucoid mutants of the biocontrol strain Pseudomonas fluorescens CHA0 show increased ability in biofilm formation on mycorrhizal and nonmycorrhizal carrot roots. Molecular plant-microbe interactions, 14: 255260.

Blachinsky, D., J. Antonov, A. Bercovitz, B. El-ad, K. Feldman, A. Husid, M. Lazare, N. Marcov, I. Shamai and S. Droby. 2007. Commercial applications of shemer for the control of pre-and post-harvest diseases. IOBC WPRS BULLETIN, 30: 75.

Branda, S. S., J. E. González-Pastor, S. Ben-Yehuda, R. Losick and R. Kolter. 2001. Fruiting body formation by Bacillus subtilis. Proceedings of the National Academy of Sciences, 98: 11621-11626.

Calvo, H., P. Marco, D. Blanco, R. Oria and M. Venturini. 2017. Potential of a new strain of Bacillus amyloliquefaciens BUZ-14 as a biocontrol agent of postharvest fruit diseases. Food microbiology, 63: 101-110.

Carmona-Hernandez, S., J. J. Reyes-Pérez, R. G. ChiquitoContreras, G. Rincon-Enriquez, C. R. CerdanCabrera and L. G. Hernandez-Montiel. 2019. Biocontrol of postharvest fruit fungal diseases by bacterial antagonists: A review. Agronomy, 9: 121.

Carroll, C. S. and M. M. Moore. 2018. Ironing out siderophore biosynthesis: a review of nonribosomal peptide synthetase (NRPS)independent siderophore synthetases. Critical Reviews in Biochemistry and Molecular Biology,
53: 356-381.

Castillo, J. D., J. M. Vivanco and D. K. Manter. 2017. Bacterial microbiome and nematode occurrence in different potato agricultural soils. Microbial ecology, 74: 888-900.

Chen, L., J. Heng, S. Qin and K. Bian. 2018. A comprehensive understanding of the biocontrol potential of Bacillus velezensis LM2303 against Fusarium head blight. PLoS One, 13: e0198560.

Chen, X., Y. Zhang, X. Fu, Y. Li and Q. Wang. 2016. Isolation and characterization of Bacillus amyloliquefaciens PG12 for the biological control of apple ring rot. Postharvest Biology and Technology, 115: 113-121.

Chen, Y., Q. Kong and Y. Liang. 2019. Three newly identified peptides from Bacillus megaterium strongly inhibit the growth and aflatoxin B1 production of Aspergillus flavus. Food Control, 95: 41-49.

Chen, Y., F. Yan, Y. Chai, H. Liu, R. Kolter, R. Losick and J. h. Guo. 2013. Biocontrol of tomato wilt disease by Bacillus subtilis isolates from natural environments depends on conserved genes mediating biofilm formation. Environmental microbiology, 15: 848-864.

Chi, M., G. Li, Y. Liu, G. Liu, M. Li, X. Zhang, Z. Sun, Y. Sui and J. Liu. 2015. Increase in antioxidant enzyme activity, stress tolerance and biocontrol efficacy of Pichia kudriavzevii with the transition from a yeast-like to biofilm morphology. Biological Control, 90: 113-119.

Colagiero, M., L. C. Rosso, D. Catalano, L. Schena and A. Ciancio. 2020. Response of Tomato Rhizosphere Bacteria to Root-Knot Nematodes, Fenamiphos and Sampling Time Shows Differential Effects on Low Level Taxa. Frontiers in microbiology, 11: 390.

Cordova-Albores, L., E. S. Zapotitla, M. Ríos, L. BarreraNecha, M. Hernández-López and S. Bautista-Baños. 2016. Microscopic study of the morphology and metabolic activity of Fusarium oxysporum f. sp. gladioli treated with Jatropha curcas oil and derivatives. Journal of microscopy and ultrastructure, 4: 28-35.

da Silva, R. S., B. L. Moutinho, D. R. dos Santos, I. Vasconcelo-Rodrigues, V. Talamini, M. F. Fernandes and R. P. Fernandes. 2018. Using antagonistic soil bacteria and their cell-free 
filtrates to control the black rot pathogen Xanthomonas campestris pv. campestris. Journal of Phytopathology, 166: 494-501.

Davies, K., M. Fargette, G. Balla, A. Daudi, R. Duponnois, S. R. Gowen, T. Mateille, M. Phillips, A. Sawadogo and C. Trivino. 2001. Cuticle heterogeneity as exhibited by Pasteuria spore attachment is not linked to the phylogeny of parthenogenetic rootknot nematodes (Meloidogyne spp.). Parasitology, 122: 111.

De Melo Pereira, G., M. Beux, M. Pagnoncelli, V. Soccol, C. Rodrigues and C. Soccol. 2016. Isolation, selection and evaluation of antagonistic yeasts and lactic acid bacteria against ochratoxigenic fungus Aspergillus westerdijkiae on coffee beans. Letters in applied microbiology, 62: 96-101.

Demoz, B. T. and L. Korsten. 2006. Bacillus subtilis attachment, colonization, and survival on avocado flowers and its mode of action on stem-end rot pathogens. Biological Control, 37: 68-74.

Di Francesco, A., C. Martini and M. Mari. 2016. Biological control of postharvest diseases by microbial antagonists: how many mechanisms of action? European Journal of Plant Pathology, 145: 711717.

Djaya, L., N. Istifadah, S. Hartati and I. M. Joni. 2019. In vitro study of plant growth promoting rhizobacteria (PGPR) and endophytic bacteria antagonistic to Ralstonia solanacearum formulated with graphite and silica nano particles as a biocontrol delivery system (BDS). Biocatalysis and Agricultural Biotechnology, 19: 101153.

Drehe, I., E. Simonetti and J. A. Ruiz. 2018. Contribution of the siderophores pyoverdine and enantiopyochelin to fitness in soil of Pseudomonas protegens Pf-5. Current microbiology, 75: 15601565.

Droby, S., M. Wisniewski, N. Teixidó, D. Spadaro and M. H. Jijakli. 2016. The science, development, and commercialization of postharvest biocontrol products. Postharvest Biology and Technology, 122: 22-29.

Etesami, H. and H. A. Alikhani. 2017. Evaluation of grampositive rhizosphere and endophytic bacteria for biological control of fungal rice (Oryzia sativa L.) pathogens. European Journal of Plant Pathology, 147: 7-14.

Feichtmayer, J., L. Deng and C. Griebler. 2017.
Antagonistic microbial interactions: contributions and potential applications for controlling pathogens in the aquatic systems. Frontiers in microbiology, 8: 2192.

Ferraz, H. G. M., R. S. Resende, P. C. Moreira, P. R. Silveira, E. A. Milagres, J. R. Oliveira and F. Á. Rodrigues. 2015. Antagonistic rhizobacteria and jasmonic acid induce resistance against tomato bacterial spot. Bragantia: 0-0.

Fialho, M. B., M. H. D. d. Moraes, A. R. Tremocoldi and S. F. Pascholati. 2011. Potential of antimicrobial volatile organic compounds to control Sclerotinia sclerotiorum in bean seeds. Pesquisa Agropecuária Brasileira, 46: 137-142.

Fravel, D. 2005. Commercialization and implementation of biocontrol. Annu. Rev. Phytopathol., 43: 337359.

Fujiwara, K., Y. Iida, N. Someya, M. Takano, J. Ohnishi, F. Terami and M. Shinohara. 2016. Emergence of Antagonism Against the Pathogenic Fungus Fusarium oxysporum by Interplay Among NonAntagonistic Bacteria in a Hydroponics Using Multiple Parallel Mineralization. Journal of Phytopathology, 164: 853-862.

Geng, C., X. Nie, Z. Tang, Y. Zhang, J. Lin, M. Sun and D. Peng. 2016. A novel serine protease, Sep1, from Bacillus firmus DS-1 has nematicidal activity and degrades multiple intestinal-associated nematode proteins. Scientific reports, 6: 1-12.

Getha, K. and S. Vikineswary. 2002. Antagonistic effects of Streptomyces violaceusniger strain G10 on Fusarium oxysporum f. sp. cubense race 4: indirect evidence for the role of antibiosis in the antagonistic process. Journal of Industrial Microbiology and Biotechnology, 28: 303-310.

Golonka, R., B. San Yeoh and M. Vijay-Kumar. 2019. The iron tug-of-war between bacterial siderophores and innate immunity. Journal of innate immunity, 11: 249-262.

Gotor-Vila, A., N. Teixidó, C. Casals, R. Torres, A. De Cal, B. Guijarro and J. Usall. 2017. Biological control of brown rot in stone fruit using Bacillus amyloliquefaciens CPA-8 under field conditions. Crop Protection, 102: 72-80.

Gu, Q., Y. Yang, Q. Yuan, G. Shi, L. Wu, Z. Lou, R. Huo, H. Wu, R. Borriss and X. Gao. 2017. Bacillomycin D produced by Bacillus amyloliquefaciens is involved in the antagonistic interaction with the plant- 
pathogenic fungus Fusarium graminearum. Applied and environmental microbiology, 83.

Guevara-Avendaño, E., A. A. Bejarano-Bolívar, A.-L. KielMartínez, M. Ramírez-Vázquez, A. Méndez-Bravo, E. A. von Wobeser, D. Sánchez-Rangel, J. A. Guerrero-Analco, A. Eskalen and F. Reverchon. 2019. Avocado rhizobacteria emit volatile organic compounds with antifungal activity against Fusarium solani, Fusarium sp. associated with Kuroshio shot hole borer, and Colletotrichum gloeosporioides. Microbiological research, 219: 7483.

Guo, H., T. M. Nolan, G. Song, S. Liu, Z. Xie, J. Chen, P. S. Schnable, J. W. Walley and Y. Yin. 2018. FERONIA receptor kinase contributes to plant immunity by suppressing jasmonic acid signaling in Arabidopsis thaliana. Current Biology, 28: 33163324. e3316.

Hacquard, S., S. Spaepen, R. Garrido-Oter and P. SchulzeLefert. 2017. Interplay between innate immunity and the plant microbiota. Annual review of Phytopathology, 55: 565-589.

Haggag, W. and S. Timmusk. 2008. Colonization of peanut roots by biofilm-forming Paenibacillus polymyxa initiates biocontrol against crown rot disease. Journal of applied microbiology, 104: 961-969.

Haidar, R., J. Roudet, O. Bonnard, M. C. Dufour, M. F. Corio-Costet, M. Fert, T. Gautier, A. Deschamps and M. Fermaud. 2016. Screening and modes of action of antagonistic bacteria to control the fungal pathogen Phaeomoniella chlamydospora involved in grapevine trunk diseases. Microbiological research, 192: 172-184.

Hasan, M. F., M. A. Islam and B. Sikdar. 2018. Biological Control of Bacterial Leaf Spot Disease of Papaya (Carica papaya) through Antagonistic Approaches using Medicinal Plants Extracts and Soil Bacteria. Int. J. Pure App. Biosci, 6: 1-11.

Hastuti, R. D., Y. Lestari, A. Suwanto and R. SARASWATI. 2012. Endophytic Streptomyces spp. as biocontrol agents of rice bacterial leaf blight pathogen (Xanthomonas oryzae pv. oryzae). HAYATI Journal of Biosciences, 19: 155-162.

Hernandez-Montiel, L. G., E. D. Gutierrez-Perez, B. Murillo-Amador, S. Vero, R. G. Chiquito-Contreras and G. Rincon-Enriquez. 2018. Mechanisms employed by Debaryomyces hansenii in biological control of anthracnose disease on papaya fruit. Postharvest Biology and Technology, 139: 31-37.

Hoang, H., L. H. Tran, T. H. Nguyen, D. A. T. Nguyen, H. H. T. Nguyen, N. B. Pham, P. Q. Trinh, T. de Boer, A. Brouwer and H. H. Chu. 2020. Occurrence of endophytic bacteria in Vietnamese Robusta coffee roots and their effects on plant parasitic nematodes. Symbiosis, 80: 75-84.

Holert, J., E. Cardenas, L. H. Bergstrand, E. Zaikova, A. S. Hahn, S. J. Hallam and W. W. Mohn. 2018. Metagenomes reveal global distribution of bacterial steroid catabolism in natural, engineered, and host environments. MBio, 9: 02345-02317.

Hong, C. E., S. H. Jo, J. Y. Moon, J.-S. Lee, S.-Y. Kwon and J. M. Park. 2015. Isolation of novel leaf-inhabiting endophytic bacteria in Arabidopsis thaliana and their antagonistic effects on phytophathogens. Plant Biotechnology Reports, 9: 451-458.

Hu, H. Q., X. S. Li and H. He. 2010. Characterization of an antimicrobial material from a newly isolated Bacillus amyloliquefaciens from mangrove for biocontrol of Capsicum bacterial wilt. Biological control, 54: 359-365.

Jamalizadeh, M., H. Etebarian, H. Aminian and A. Alizadeh. 2011. A review of mechanisms of action of biological control organisms against postharvest fruit spoilage. EPPO Bulletin, 41: 65-71.

James, D. and S. Mathew. 2015. Antagonistic activity of endophytic microorganisms against bacterial wilt disease of tomato.

Janisiewicz, W. and D. Peterson. 2004. Susceptibility of the stem pull area of mechanically harvested apples to blue mold decay and its control with a biocontrol agent. Plant Disease, 88: 662-664.

Janisiewicz, W. J. and L. Korsten. 2002. Biological control of postharvest diseases of fruits. Annual review of phytopathology, 40: 411-441.

Jatala, P. 1986. Biological control of plant-parasitic nematodes. Annual review of phytopathology, 24: 453-489.

Jensen, B. D., S. M. Massomo, I. S. Swai, J. Hockenhull and S. B. Andersen. 2005. Field evaluation for resistance to the black rot pathogen Xanthomonas campestris pv. campestris in cabbage (Brassica oleracea). European journal of plant pathology, 113: 297-308.

Jiang, C.-H., F. Wu, Z.-Y. Yu, P. Xie, H.-J. Ke, H.-W. Li, Y.-Y. 
Yu and J.-H. Guo. 2015. Study on screening and antagonistic mechanisms of Bacillus amyloliquefaciens 54 against bacterial fruit blotch (BFB) caused by Acidovorax avenae subsp. citrulli. Microbiological research, 170: 95-104.

Jin, P., H. Wang, Z. Tan, Z. Xuan, G. Y. Dahar, Q. X. Li, W. Miao and W. Liu. 2020. Antifungal mechanism of bacillomycin D from Bacillus velezensis $\mathrm{HN}-2$ against Colletotrichum gloeosporioides Penz. Pesticide Biochemistry and Physiology, 163: 102107.

Junaid, J. M., N. A. Dar, T. A. Bhat, A. H. Bhat and M. A. Bhat. 2013. Commercial biocontrol agents and their mechanism of action in the management of plant pathogens. International Journal of Modern Plant \& Animal Sciences, 1: 39-57.

Kaufman, G., W. Liu, D. M. Williams, Y. Choo, M. Gopinadhan, N. Samudrala, R. Sarfati, E. C. Yan, L. Regan and C. O. Osuji. 2017. Flat Drops, Elastic Sheets, and Microcapsules by Interfacial Assembly of a Bacterial Biofilm Protein, BslA. Langmuir, 33: 13590-13597.

Kheirandish, Z. and B. Harighi. 2015. Evaluation of bacterial antagonists of Ralstonia solanacearum, causal agent of bacterial wilt of potato. Biological Control, 86: 14-19.

Khoa, N. Đ., N. Đ. N. Giàu and T. Q. Tuấn. 2016. Effects of Serratia nematodiphila CT-78 on rice bacterial leaf blight caused by Xanthomonas oryzae pv. oryzae. Biological Control, 103: 1-10.

Kim, Y. S., K. Balaraju and Y. Jeon. 2016. Effects of rhizobacteria Paenibacillus polymyxa APEC136 and Bacillus subtilis APEC170 on biocontrol of postharvest pathogens of apple fruits. Journal of Zhejiang University-SCIENCE B, 17: 931-940.

Kobayashi, K. and M. Iwano. 2012. BslA (YuaB) forms a hydrophobic layer on the surface of Bacillus subtilis biofilms. Molecular microbiology, 85: 5166.

Koenning, S., C. Overstreet, J. Noling, P. Donald, J. Becker and B. Fortnum. 1999. Survey of crop losses in response to phytoparasitic nematodes in the United States for 1994. Journal of nematology, 31: 587.

Köhl, J., R. Kolnaar and W. J. Ravensberg. 2019. Mode of action of microbial biological control agents against plant diseases: relevance beyond efficacy. Frontiers in Plant Science, 10: 845.
Kowalska, J., D. Rożdżyński, D. Remlein-Starosta, L. SasPaszt and E. Malusá. 2012. Use of Cryptococcus albidus for controlling grey mould in the production and storage of organically grown strawberries. Journal of Plant Diseases and Protection, 119: 174-178.

Kumar, V., L. Jain, S. K. Jain, S. Chaturvedi and P. Kaushal. 2020. Bacterial endophytes of rice (Oryza sativa L.) and their potential for plant growth promotion and antagonistic activities. South African Journal of Botany.

Layton, C., E. Maldonado, L. Monroy, L. C. C. Ramírez and L. C. S. Leal. 2011. Bacillus spp.; perspectiva de su efecto biocontrolador mediante antibiosis en cultivos afectados por fitopatógenos. Nova, 9: 177187.

Lima, G., S. M. Sanzani, F. De Curtis and A. Ippolito. 2015. Biological control of postharvest diseases. Advances in Postharvest Fruit and Vegetables Technology; Wills, RBH, Golding, JB, Eds: 65-81.

Lin, F., Y. Xue, Z. Huang, M. Jiang, F. Lu, X. Bie, S. Miao and Z. Lu. 2019. Bacillomycin D inhibits growth of Rhizopus stolonifer and induces defense-related mechanism in cherry tomato. Applied microbiology and biotechnology, 103: 7663-7674.

Liu, H., L. C. Carvalhais, M. Crawford, E. Singh, P. G. Dennis, C. M. Pieterse and P. M. Schenk. 2017. Inner plant values: diversity, colonization and benefits from endophytic bacteria. Frontiers in microbiology, 8: 2552.

Lugtenberg, B. and F. Kamilova. 2009. Plant-growthpromoting rhizobacteria. Annual review of microbiology, 63: 541-556.

Luo, J., W. Xia, P. Cao, Z. a. Xiao, Y. Zhang, M. Liu, C. Zhan and N. Wang. 2019. Integrated transcriptome analysis reveals plant hormones jasmonic acid and salicylic acid coordinate growth and defense responses upon fungal infection in poplar. Biomolecules, 9: 12.

Maida, I., C. Chiellini, A. Mengoni, E. Bosi, F. Firenzuoli, M. Fondi and R. Fani. 2016. Antagonistic interactions between endophytic cultivable bacterial communities isolated from the medicinal plant $E$ chinacea purpurea. Environmental microbiology, 18: 2357-2365.

Mankau, R. 1980. Biological control of nematode pests by natural enemies. Annual Review of Phytopathology, 18: 415-440. 
Mankau, R., J. Imbriani and A. Bell. 1976. SEM observations on nematode cuticle penetration by Bacillus penetrans. Journal of Nematology, 8: 179.

Mendoza de Gives, P., K. G. Davies, M. Morgan and J. M. Behnke. 1999. Attachment tests of Pasteuria penetrans to the cuticle of plant and animal parasitic nematodes, free living nematodes and srf mutants of Caenorhabditis elegans. Parasitology, 73.

Monteiro, F. P., L. C. Ferreira, L. P. Pacheco and P. E. Souza. 2013. Antagonism of Bacillus subtilis against Sclerotinia sclerotiorum on Lactuca sativa. Journal of Agricultural Science, 5: 214.

Monteiro, L., R. d. L. R. Mariano and A. M. Souto-Maior. 2005. Antagonism of Bacillus spp. against Xanthomonas campestris pv. campestris. Brazilian Archives of Biology and Technology, 48: 23-29.

Mu, J., X. Li, J. Jiao, G. Ji, J. Wu, F. Hu and H. Li. 2017. Biocontrol potential of vermicompost through antifungal volatiles produced by indigenous bacteria. Biological Control, 112: 49-54.

Mun, B.-G., W.-H. Lee, S.-M. Kang, S.-U. Lee, S.-M. Lee, D. Y. Lee, M. Shahid, B.-W. Yun and I.-J. Lee. 2020. Streptomyces sp. LH 4 promotes plant growth and resistance against Sclerotinia sclerotiorum in cucumber via modulation of enzymatic and defense pathways. Plant and Soil: 1-17.

Nishida, M., T. Matsubara and N. Watanabe. 1965. Pyrrolnitrin, a new antifungal antibiotic Microbiological and toxicological observations. The Journal of Antibiotics, Series A, 18: 211-219.

Novinscak, A., V. J. Gadkar, D. L. Joly and M. Filion. 2016. Complete genome sequence of Pseudomonas brassicacearum LBUM300, a disease-suppressive bacterium with antagonistic activity toward fungal, oomycete, and bacterial plant pathogens. Genome Announcements, 4.

Nunes, C. A. 2012. Biological control of postharvest diseases of fruit. European Journal of Plant Pathology, 133: 181-196.

Ongena, M. and P. Jacques. 2008. Bacillus lipopeptides: versatile weapons for plant disease biocontrol. Trends in microbiology, 16: 115-125.

Ostrowski, A., A. Mehert, A. Prescott, T. B. Kiley and N. R. Stanley-Wall. 2011. YuaB functions synergistically with the exopolysaccharide and TasA amyloid fibers to allow biofilm formation by Bacillus subtilis. Journal of bacteriology, 193: 4821-4831.
Öztürk, L., T. Behmand, G. G. Avcl, R. Bozbuğa, M. Mirik and İ. H. Elekcioğlu. 2020. Survey of Pasteuria, the parasitic bacterial group to plant parasitic nematodes in Turkey. Egyptian Journal of Biological Pest Control, 30: 1-7.

Pusey, P., V. Stockwell, C. Reardon, T. Smits and B. Duffy. 2011. Antibiosis activity of Pantoea agglomerans biocontrol strain E325 against Erwinia amylovora on apple flower stigmas. Phytopathology, 101: 1234-1241.

Raaijmakers, J. M. and M. Mazzola. 2012. Diversity and natural functions of antibiotics produced by beneficial and plant pathogenic bacteria. Annual review of phytopathology, 50: 403-424.

Roberts, P., M. Momol, L. Ritchie, S. Olson, J. Jones and B. Balogh. 2008. Evaluation of spray programs containing famoxadone plus cymoxanil, acibenzolar-S-methyl, and Bacillus subtilis compared to copper sprays for management of bacterial spot on tomato. Crop Protection, 27: 1519-1526.

Romero, D., H. Vlamakis, R. Losick and R. Kolter. 2011. An accessory protein required for anchoring and assembly of amyloid fibres in B. subtilis biofilms. Molecular microbiology, 80: 1155-1168.

Rybakova, D., U. Wetzlinger, H. Müller and G. Berg. 2015. Complete genome sequence of Paenibacillus polymyxa strain Sb3-1, a soilborne bacterium with antagonistic activity toward plant pathogens. Genome announcements, 3.

Safdarpour, F. and G. Khodakaramian. 2019. Assessment of antagonistic and plant growth promoting activities of tomato endophytic bacteria in challenging with Verticillium dahliae under invitro and in-vivo conditions. Biological Journal of Microorganism, 7: 77-90.

Sajitha, K. and S. A. Dev. 2016. Quantification of antifungal lipopeptide gene expression levels in Bacillus subtilis B1 during antagonism against sapstain fungus on rubberwood. Biological Control, 96: 78-85.

Salerno, C. and M. Sagardoy. 2003. Antagonistic activity by" Bacillus subtilis" against" Xanthomonas campestris" pv." glycines" aunder controlled conditions. Spanish journal of agricultural research: 55-58.

Sarangi, T., S. Ramakrishnan and S. Nakkeeran. 2017. Antimicrobial Peptide Genes Present in 
Indigenous Isolates of Bacillus spp. Exhibiting Antimicrobical Properties. Int. J. Curr. Microbiol. App. Sci, 6: 1361-1369.

Sayre, R. M. and W. P. Wergin. 1977. Bacterial parasite of a plant nematode: morphology and ultrastructure. Journal of Bacteriology, 129: 1091-1101.

Schneider, S. M., E. N. Rosskopf, J. G. Leesch, D. 0. Chellemi, C. T. Bull and M. Mazzola. 2003. United States Department of Agriculture-Agricultural Research Service research on alternatives to methyl bromide: pre-plant and post-harvest. Pest Management Science: formerly Pesticide Science, 59: 814-826.

Sebastien, M. and M. H. Jijakli. 2014. Pichia anomala and Candida oleophila in biocontrol of postharvest diseases of fruits: 20 years of fundamental and practical research, Post-harvest Pathology. Springer, pp. 111-122.

Seidl, V. 2008. Chitinases of filamentous fungi: a large group of diverse proteins with multiple physiological functions. Fungal Biology Reviews, 22: 36-42.

Selin, C., R. Habibian, N. Poritsanos, S. N. Athukorala, D. Fernando and T. R. De Kievit. 2009. Phenazines are not essential for Pseudomonas chlororaphis PA23 biocontrol of Sclerotinia sclerotiorum, but do play a role in biofilm formation. FEMS microbiology ecology, 71: 73-83.

Semeniuc, C. A., C. R. Pop and A. M. Rotar. 2017. Antibacterial activity and interactions of plant essential oil combinations against Gram-positive and Gram-negative bacteria. journal of food and drug analysis, 25: 403-408.

Shakeel, Q., A. Lyu, J. Zhang, M. Wu, G. Li, T. Hsiang and L. Yang. 2018. Biocontrol of Aspergillus flavus on peanut kernels using Streptomyces yanglinensis 310. Frontiers in Microbiology, 9: 1049.

Sharifazizi, M., B. Harighi and A. Sadeghi. 2017. Evaluation of biological control of Erwinia amylovora, causal agent of fire blight disease of pear by antagonistic bacteria. Biological Control, 104: 28-34.

Sharma, R., D. Singh and R. Singh. 2009. Biological control of postharvest diseases of fruits and vegetables by microbial antagonists: A review. Biological control, 50: 205-221.

Shivakumar, S., A. N. Karmali and C. Ruhimbana. 2014. Partial purification, characterization, and kinetic studies of a low-molecular-weight, alkali-tolerant chitinase enzyme from Bacillus subtilis JN032305, a potential biocontrol strain. Preparative Biochemistry and Biotechnology, 44: 617-632.

Shrestha, B. K., H. S. Karki, D. E. Groth, N. Jungkhun and J. H. Ham. 2016. Biological control activities of riceassociated Bacillus sp. strains against sheath blight and bacterial panicle blight of rice. PloS one, 11: e0146764.

Siddiqui, Z. and I. Mahmood. 1999. Role of bacteria in the management of plant parasitic nematodes: a review. Bioresource technology, 69: 167-179.

Soliman, G. M., H. H. Ameen, S. M. Abdel-Aziz and G. M. ElSayed. 2019. In vitro evaluation of some isolated bacteria against the plant parasite nematode Meloidogyne incognita. Bulletin of the National Research Centre, 43: 171.

Spadaro, D. and S. Droby. 2016. Development of biocontrol products for postharvest diseases of fruit: the importance of elucidating the mechanisms of action of yeast antagonists. Trends in Food Science \& Technology, 47: 39-49.

Stirling, G. R. 1991. Biological control of plant parasitic nematodes. CAB International.

Stoykov, Y. M., A. I. Pavlov and A. I. Krastanov. 2015. Chitinase biotechnology: production, purification, and application. Engineering in Life Sciences, 15: 30-38.

Subhalaxmi, R., R. Aran and P. Aniruddha. 2017. Nematicidal activity of Bacillus subtilis against root knot nematode Meloidogyne incognita (kofoid and white) chitwood in tomato. Environment and Ecology, 35: 469-473.

Taghavi, S., C. Garafola, S. Monchy, L. Newman, A. Hoffman, N. Weyens, T. Barac, J. Vangronsveld and D. van der Lelie. 2009. Genome survey and characterization of endophytic bacteria exhibiting a beneficial effect on growth and development of poplar trees. Applied and environmental microbiology, 75: 748-757.

Tahir, H. A. S., Q. Gu, H. Wu, Y. Niu, R. Huo and X. Gao. 2017. Bacillus volatiles adversely affect the physiology and ultra-structure of Ralstonia solanacearum and induce systemic resistance in tobacco against bacterial wilt. Scientific reports, 7: 1-15.

Tan, H., L. Cao, Z. He, G. Su, B. Lin and S. Zhou. 2006. Isolation of endophytic actinomycetes from 
different cultivars of tomato and their activities against Ralstonia solanacearum in vitro. World Journal of Microbiology and Biotechnology, 22: 1275-1280.

Teixidó, N., R. Torres, I. Viñas, M. Abadias and J. Usall. 2011. Biological control of postharvest diseases in fruit and vegetables, Protective Cultures, Antimicrobial Metabolites and Bacteriophages for Food and Beverage Bio preservation. Elsevier, pp. 364-402.

Terpilowska, S. and A. K. Siwicki. 2019. Cell cycle and transmembrane mitochondrial potential analysis after treatment with chromium (iii), iron (iii), molybdenum (iii) or nickel (ii) and their mixtures. Toxicology research, 8: 188-195.

Thokchom, E., D. Thakuria, M. C. Kalita, C. K. Sharma and N. C. Talukdar. 2017. Root colonization by hostspecific rhizobacteria alters indigenous root endophyte and rhizosphere soil bacterial communities and promotes the growth of mandarin orange. European Journal of Soil Biology, 79: 48-56.

Thomas, P. and A. C. Sekhar. 2016. Effects due to rhizospheric soil application of an antagonistic bacterial endophyte on native bacterial community and its survival in soil: a case study with Pseudomonas aeruginosa from Banana. Frontiers in microbiology, 7: 493.

Thomashow, L. S. 2002. Antibiotic production by soil and rhizosphere microbes in situ. Manual of environmental microbiology.

Tian, B., J. Yang and K.-Q. Zhang. 2007. Bacteria used in the biological control of plant-parasitic nematodes: populations, mechanisms of action, and future prospects. FEMS microbiology ecology, 61: 197-213.

Topalović, 0., A. Elhady, J. Hallmann, K. R. RichertPöggeler and H. Heuer. 2019. Bacteria isolated from the cuticle of plant-parasitic nematodes attached to and antagonized the root-knot nematode Meloidogyne hapla. Scientific reports, 9: 1-13.

Torres, M. J., C. P. Brandan, G. Petroselli, R. Erra-Balsells and M. C. Audisio. 2016. Antagonistic effects of Bacillus subtilis subsp. subtilis and $B$. amyloliquefaciens against Macrophomina phaseolina: SEM study of fungal changes and UVMALDI-TOF MS analysis of their bioactive compounds. Microbiological research, 182: 31-39.

Torres, R., C. Solsona, I. Viñas, J. Usall, P. Plaza and N. Teixidó. 2014. Optimization of packaging and storage conditions of a freeze-dried $P$ antoea agglomerans formulation for controlling postharvest diseases in fruit. Journal of applied microbiology, 117: 173-184.

Upreti, R. and P. Thomas. 2015. Root-associated bacterial endophytes from Ralstonia solanacearum resistant and susceptible tomato cultivars and their pathogen antagonistic effects. Frontiers in microbiology, 6: 255.

Usall, J., R. Torres and N. Teixido. 2016. Biological control of postharvest diseases on fruit: a suitable alternative? Current Opinion in Food Science, 11: 51-55.

Vagelas, I. and S. Gowen. 2012. Control of Fusarium oxysporum and root-knot nematodes (Meloidogyne spp.) with Pseudomonas oryzihabitans. Pak. J. Phytopathol, 24: 32-38.

Velázquez-Becerra, C., L. I. Macías-Rodríguez, J. LópezBucio, I. Flores-Cortez, G. Santoyo, C. HernándezSoberano and E. Valencia-Cantero. 2013. The rhizobacterium Arthrobacter agilis produces dimethyl hexadecylamine, a compound that inhibits growth of phytopathogenic fungi in vitro. Protoplasma, 250: 1251-1262.

Vlamakis, H., C. Aguilar, R. Losick and R. Kolter. 2008. Control of cell fate by the formation of an architecturally complex bacterial community. Genes \& development, 22: 945-953.

Waewthongrak, W., S. Pisuchpen and W. Leelasuphakul. 2015. Effect of Bacillus subtilis and chitosan applications on green mold (Penicilium digitatum Sacc.) decay in citrus fruit. Postharvest Biology and Technology, 99: 44-49.

Wang, J., J. Wang, F. Liu and C. Pan. 2010. Enhancing the virulence of Paecilomyces lilacinus against Meloidogyne incognita eggs by overexpression of a serine protease. Biotechnology letters, 32: 11591166.

Wang, X., Q. Li, J. Sui, J. Zhang, Z. Liu, J. Du, R. Xu, Y. Zhou and X. Liu. 2019. Isolation and characterization of antagonistic bacteria Paenibacillus jamilae HS-26 and their effects on plant growth. Bio-Medicine research international.

Wicaksono, W. A., E. E. Jones, S. Casonato, J. Monk and H. J. Ridgway. 2018. Biological control of 
Pseudomonas syringae pv. actinidiae (Psa), the causal agent of bacterial canker of kiwifruit, using endophytic bacteria recovered from a medicinal plant. Biological control, 116: 103-112.

Wu, L., H. Shang, Q. Wang, H. Gu, G. Liu and S. Yang. 2016. Isolation and characterization of antagonistic endophytes from Dendrobium candidum Wall ex Lindl., and the biofertilizing potential of a novel Pseudomonas saponiphila strain. Applied Soil Ecology, 105: 101-108.

Xia, Y., S. Xie, X. Ma, H. Wu, X. Wang and X. Gao. 2011. The purL gene of Bacillus subtilis is associated with nematicidal activity. FEMS microbiology letters, 322: 99-107.

$\mathrm{Xu}$, G. and D. Gross. 1986. Selection of fluorescent pseudomonads antagonistic to Erwinia carotovora and suppressive of potato seed piece decay. Phytopathology, 76: 414-422.

Yadav, A. N., P. Verma, D. Kour, K. L. Rana, V. Kumar, B. Singh, V. S. Chauahan, T. Sugitha, A. K. Saxena and H. S. Dhaliwal. 2017. Plant microbiomes and its beneficial multifunctional plant growth promoting attributes. International journal of environmental sciences, 3: 1-8.

Yasmin, S., F. Y. Hafeez, M. S. Mirza, M. Rasul, H. M. Arshad, M. Zubair and M. Iqbal. 2017. Biocontrol of bacterial leaf blight of rice and profiling of secondary metabolites produced by rhizospheric Pseudomonas aeruginosa BRp3. Frontiers in Microbiology, 8: 1895.

Yasmin, S., A. Zaka, A. Imran, M. A. Zahid, S. Yousaf, G. Rasul, M. Arif and M. S. Mirza. 2016. Plant growth promotion and suppression of bacterial leaf blight in rice by inoculated bacteria. PloS one, 11: e0160688.

Yu, S. M. and Y. H. Lee. 2015. Genes involved in nutrient competition by Pseudomonas putida JBC17 to suppress green mold in postharvest satsuma mandarin. Journal of basic microbiology, 55: 898906.

Yu, T., L. Wang, Y. Yin, Y. Wang and X. Zheng. 2008. Effect of chitin on the antagonistic activity of Cryptococcus laurentii against Penicillium expansum in pear fruit. International Journal of Food Microbiology, 122: 44-48.

Zeng, J., T. Xu, L. Cao, C. Tong, X. Zhang, D. Luo, S. Han, P. Pang, W. Fu and J. Yan. 2018. The role of iron competition in the antagonistic action of the rice endophyte Streptomyces sporocinereus OsiSh-2 against the pathogen Magnaporthe oryzae. Microbial ecology, 76: 1021-1029.

Zhang, L., X. Tian, S. Kuang, G. Liu, C. Zhang and C. Sun. 2017. Antagonistic activity and mode of action of phenazine-1-carboxylic acid, produced by marine bacterium Pseudomonas aeruginosa PA31x, against Vibrio anguillarum in vitro and in a zebrafish in vivo model. Frontiers in microbiology, 8: 289.

Zhang, X., B. Li, Y. Wang, Q. Guo, X. Lu, S. Li and P. Ma. 2013. Lipopeptides, a novel protein,and volatile compounds contribute to the antifungal activity of the biocontrol agent Bacillus atrophaeus CAB-1. Applied microbiology and biotechnology, 97: 9525-9534.

ZhouG.Yuen, Y. Wang, L. Wei and G. Ji. 2016. Evaluation of bacterial biological control agents for control of root-knot nematode disease on tomato. Crop Protection, 84: 8-13.

ZhuangX., J. Chen, H. Shim and Z. Bai. 2007. New advances in plant growth-promoting rhizobacteria for bioremediation. Environment international, 33: 406-413.

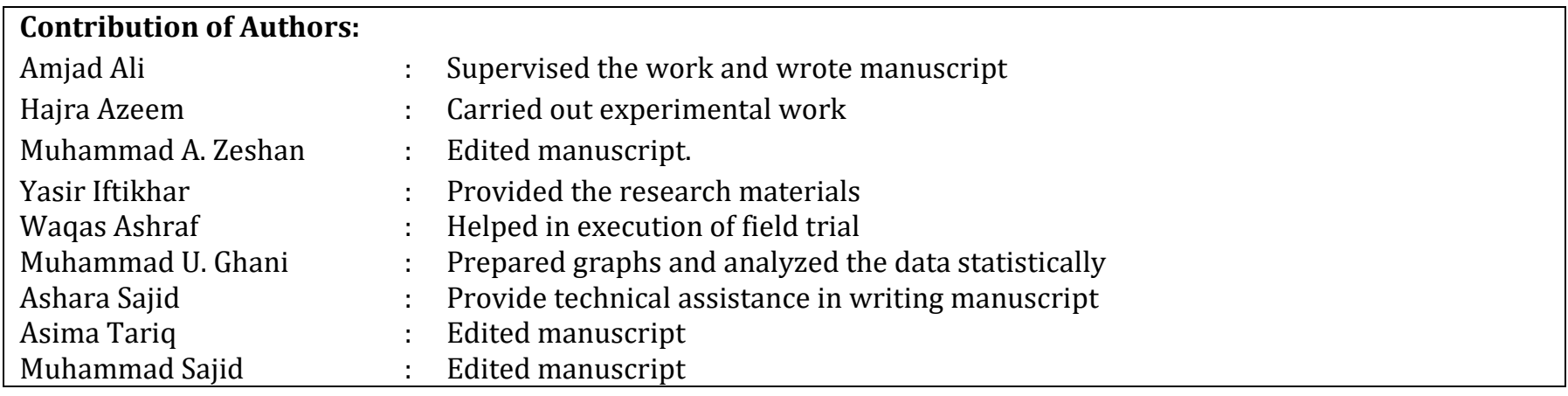

